\title{
PENGARUH KEMAMPUAN TEKNIK PERSONAL, PELATIHAN OPERATOR SISTEM TERHADAP KINERJA SISTEM MANAJEMEN DAERAH (SIMDA) KEUANGAN MELALUI ADOPSI LAYANAN DI PEMERINTAH KABUPATEN BONDOWOSO
}

\author{
Eko Slamet Wahyudi \\ Fakultas Ekonomi dan Bisnis Universitas Jember \\ ekosw123@gmail.com \\ Diana Sulianti K. Tobing \\ Fakultas Ekonomi dan Bisnis Universitas Jember \\ dsklt@yahoo.com \\ Handriyono \\ Fakultas Ekonomi dan Bisnis Universitas Jember \\ handriex@yahoo.co.id
}

\begin{abstract}
This study aims to analyze the effect of personal technical ability and training of information system operator on the performance of local management system (SIMDA) mediated by actual usage in the Government of Bondowoso Regency. This is a quantitative research using explanatory approach. The population was all operators of SIMDA/the compilers of financial statements. The research sample consisted of 62 respondents. Data were analyzed using path analysis. The results showed that the personal technical ability of the information system operator had a significant effect on the performance of SIMDA and actual usage; training of system users had no effect on performance of SIMDA and actual usage; and actual usage had a significant effect on performance of SIMDA.
\end{abstract}

Keywords: Personal Technical Ability, System Operator Training, Performance, and Actual Usage

Abstrak: Penelitian ini bertujuan untuk menganalisis pengaruh kemampuan teknik personal dan pelatihan operator sistem informasi terhadap Kinerja Sistem Manajemen Daerah (SIMDA) Keuangan melalui adopsi layanan (actual usage) di Pemerintah Kabupaten Bondowoso. Penelitian ini merupakan penelitian kuantitatif dengan pendekatan explanatory research. Populasi dalam penelitian ini adalah operator SIMDA/penyusun laporan keuangan di Pemerintah Kabupaten Bondowoso dengan sampel terdiri dari 62 operator. Data yang diperoleh dari pengisian kuesioner responden diuji menggunakan uji analisis jalur (path analysis). Hasil penelitian menunjukkan bahwa kemampuan teknik personal sistem informasi berpengaruh signifikan terhadap kinerja SIMDA dan adopsi layanan; pelatihan pada pemakai sistem tidak berpengaruh terhadap kinerja SIMDA dan adopsi layanan; dan adopsi layanan berpengaruh signifikan terhadap kinerja SIMDA.

Kata Kunci: Kemampuan Teknik Personal, Pelatihan Operator Sistem, Kinerja, dan Adopsi Layanan. 


\section{Pendahuluan}

Menurut BPKP 2017, Program Aplikasi SIMDA telah diimplementasikan pada 425 Pemda dari 542 pemerintah daerah yang ada atau sebanyak 78,41\%. Sementara dari 425 Pemda yang telah mengimplementasikan SIMDA secara keseluruhan belum berjalan secara optimal. Hal ini dibuktikan dari Ikhtisar Hasil Pemeriksaan Semester (IHPS) 2015 yang menyatakan bahwa: Strategi komprehensif belum ada, SDM dan sistem aplikasi tidak siap serta perangkat regulasi belum lengkap. Sedangkan berdasarkan hasil pemeriksaan dari BPK-RI pada Ikhtisar Hasil Pemeriksaan Semester (IHPS) Tahun 2016, masih ditemukan permasalahan terkait dengan sistem antara lain (BPK Rl, 2016) : Sistem pelaporan keuangan yang telah ditetapkan belum dapat menjamin akurasi dan kelengkapan informasi keuangan, belum terintegrasinya sistem informasi, dan sistem aplikasi belum menjamin akurasi penyajian akun.

Kinerja sebuah sistem informasi pemerintahan baik buruknya dapat dilihat dari keputusan pemakai sistem informasi pemerintahan itu sendiri. Suatu sistem informasi akan sukses apabila didukung oleh beberapa faktor pendukungnya. Menurut Soegiharto dan Tjhai Fung Jen (dalam Almilia et al., 2006) beberapa faktor yang berpengaruh terhadap kinerja SIMDA pemerintahan, antara lain: keterlibatan pemakai dalam pengembangan sistem, kemampuan teknik personal sistem informasi, dukungan manajemen puncak, formalisasi pengembangan sistem informasi, serta pelatihan pemakai Sistem Informasi pemerintahan.

Pengguna sistem informasi bisa mendapatkan kemampuan dengan pelatihan untuk mengidentifikasi persyaratan informasi dan kesungguhan serta keterbatasan sistem informasi dan kemampuan ini dapat mengarah pada peningkatan kinerja. Sebelum menerima atas sistem yang baru, sesorang terlebih dahulu akan mengetahui adanya perubahan tersebut dan kemudian akan berusaha untuk memahaminya. Hal tersebut dapat dicapai melalui pelatihan yang tepat. Pelatihan juga akan meningkatkan rasa percaya diri karyawan dalam menghadapi sistem yang baru (Lestari, , 2010:22). Komara dan Acep (2005) faktor pelatihan pengguna, komite pengendalian SI dan lokasi departemen SI terhadap kepuasan pengguna dan penggunaan sistem informasi tidak berpengaruh terhadap kinerja SIA. Karikari et al (2015) meneliti tentang pengaruh pelatihan terhadap kinerja SIMDA. Hasil penelitian ini ditemukan bahwa pelatihan berpengaruh terhadap sistem informasi perusahaan. 
Kemampuan teknik personal pemakai sistem informasi berperan penting dalam pengembangan sistem informasi untuk dapat menghasilkan informasi guna menciptakan laporan perencanaan yang akurat. Setiap karyawan harus dapat menguasai penggunaan sistem berbasis komputer agar dapat memproses sejumlah transaksi dengan cepat dan terintegrasi, dapat menyimpan data dan mengambil data dalam jumlah yang besar, dapat mengurangi kesalahan matematik, menghasilkan laporan tepat waktu dalam berbagai bentuk, serta dapat menjadi alat bantu keputusan (Yulian, 2011:6). Jen et al. (2002) berpendapat bahwa semakin tinggi kemampuan teknik personal SIA akan meningkatkan kinerja SIA dikarenakan adanya hubungan positif antara kemampuan teknik personal SIA dengan kinerja SIA (Komara dan Acep, 2005), (Jen et al., 2002) dan (Almilia dan Briliantine, 2007)). Penelitian Jen (2002) menunjukkan bahwa variabel kemampuan teknik personal sistem informasi berdasarkan koefisien korelasinya menunjukkan hubungan positif terhadap variabel kepuasan pengguna sedangkan Almilia dan Briliantine (2007) menunjukkan bahwa tidak terdapat hubungan yang signifikan antara keterlibatan pengguna dalam proses pengembangan sistem dengan kinerja SIA. Alfian dan Mohammad (2014) menguji pengaruh dukungan manajemen puncak, tingkat pemahaman pengguna mengenai SIMDA, kualitas data input pada implementasi SIMDA dan menyatakan bahwa kualitas data input dan dukungan manajemen puncak berpengaruh positif pada pelaksanaan SIMDA, tetapi tingkat pengetahuan pengguna tentang SIMDA tidak berpengaruh positif terhadap implementasi SIMDA. Menurut Srimindarti et al. (2012) mengungkapkan bahwa kemampuan teknik personal disini berkaitan dengan kemampuan yang dimiliki oleh pemakai sistem informasi akuntansi. Hashim et.al (2012) menemukan bahwa kemampuan personal dan pelatihan sistem informasi dapat berpengaruh terhadap kinerja SIMDA.

Implementasi SIMDA di Pemerintah Kabupaten Bondowoso telah dilaksanakan sejak tahun 2011. SIMDA yang digunakan pada waktu itu adalah SIMDA versi 2.1. Pencapaian dari implementasi SIMDA di Pemerintah Kabupaten Bondowoso masih di nilai belum maksimal. Hal ini dibuktikan dari hasil pemeriksaan BPK Tahun 2016, yang menyatakan bahwa implementasi SIMDA di Pemerintah Kabupaten Bondowoso belum sepenuhnya digunakan secara optimal baik dari segi Sistem Teknologi Informasi yang tidak dapat mendukung serta pemahaman akuntansi dari masing masing operator yang masih terbatas. 
Penelitian ini mempunyai tujuan sebagai berikut (a) Untuk menguji dan menganalisis pengaruh signifikan kemampuan teknik personal sistem informasi terhadap kinerja SIMDA; (b) Untuk menguji dan menganalisis pengaruh signifikan pelatihan pemakai sistem terhadap kinerja SIMDA; (c) Untuk menguji dan menganalisis pengaruh signifikan kemampuan teknik personal sistem informasi terhadap adopsi layanan SIMDA; (d) Untuk menguji dan menganalisis pengaruh signifikan pelatihan pemakai sistem terhadap adopsi layanan SIMDA (e) Untuk menguji dan menganalisis pengaruh signifikan adopsi layanan SIMDA terhadap kinerja SIMDA.

\section{Metodologi}

Jenis data dalam penelitian ini yaitu data subyek (self-report data) yang berupa respon tertulis (opini) yang diberikan kepada subyek penelitian, dalam hal ini adalah responden, sebagai tanggapan/pernyataan tertulis (kuisioner) yang diajukan oleh peneliti. Populasi yang diambil dalam penelitian ini adalah operator SIMDA Organisasi Perangkat Daerah OPD) yang berada di Pemerintah Kabupaten Bondowoso sebanyak 62 orang. Sampel peneltiian menggunakan metode sensus dimana seluruh populais menjadi sampel sebanyak 62 orang operator SIMDA di OPD Pemerintah Kabupaten Bondowoso.

Variabel-variabel yang akan digunakan dalam penelitian ini, maka berikut dikemukakan definisi operasional variabel dengan maksud untuk memberikan gambaran tentang konsep masing-masing variabel sehingga tidak bias interpretasi.

a. Variabel Independen

Ada 2 (dua) variabel independen dalam penelitian ini, yaitu :

1. Variabel kemampuan teknik personal (X1) ini berkaitan dengan kompetensi dalam menggunakan pengetahuan, metode, teknik dan peralatan yang dipergunakan untuk melaksanakan tugas serta pengalaman dan pelatihan yang diperolehnya. Kemampuan teknik personal diukur dengan indikator sebagai berikut :

a) Pengetahuan (knowledge) yaitu informasi yang dimiliki seseorang untuk melaksanakan tugas dan tanggung jawab sesuai dengan bidang yang di gelutinya, diukur melalui :

1) Pengetahuan dan pemahaman tugas dan tanggung jawab dalam bekerja di bidang sistem informasi.

2) Pengetahuan tupoksi organisasi instansi. 
b) Kemampuan (abilities) didasarkan pada kompetensi pemakai sistem informasi dalam menjalankan sistem informasi yang ada dengan item:

1) Kemampuan menjalankan sistem informasi.

2) Kemampuan untuk mengetahui informasi yang dibutuhkan.

c) Keahlian (skills) adalah ketrampilan yang dimiliki operator SIMDA dalam melaksanakan pekerjaannya.

2. Variabel program pelatihan (X2) ini berkaitan dengan mengukur keefektivitas dari kegiatan pelatihan sehingga pelatihan tersebut dapat memberikan kontribusi yang optimal. Indikator pelatihan diukur dengan :

a) Jenis pelatihan terdiri dari :

1) Pelatihan penganggaran/ perencanaan (penyusunan Rencana Kerja Anggaran (RKA), Dokumen Pelaksanaan Anggaran (DPA),

2) Pelatihan penatausahaan (entry data pembuatan SPP dan SPM),

3) Pelatihan penyusunan pelaporan keuangan

b) Peserta pelatihan adalah orang yang diseleksi berdasarkan persyaratan tertentu dan kualifikasi yang sesuai. Peserta pelatihan yang tidak sesuai dengan kriteria yang di syaratkan oleh kegiatan pelatihan dapat menyebabkan terjadinya penggunaan alokasi waktu, dana, dan energi yang berlebihan bahkan sia-sia dalam kegiatan pelatihan SDM.

c) Waktu pelaksanaan adalah periode waktu yang diperlukan untuk melaksanakan pelatihan.

d) Metode dan teknik diukur dengan banyaknya teori dan praktek dalam kegiatan pelatihan SDM.

e) Instruktur yaitu seseorang atau tim yang ahli dalam memberikan pelatihan SIMDA Keuangan.

f) Materi diukur sesuai dengan perkembangan SIMDA terbaru.

b. Variabel interviening

Adopsi Layanan/ Actual usage ( $\mathrm{Z}$ ) dalam penelitian ini merupakan bentuk nyata adopsi layanan SIMDA yang dikonsepkan dalam bentuk pengukuran terhadap frekuensi dan durasi waktu penggunaan teknologi. Ada 6 dimensi untuk mengukur variabel actual usage dengan indikator-indikator yaitu

1. Kontinu atau terus menerus dimana sistem dilakukan terus menerus sesuai kebutuhan

2. Hasil output SIMDA dapat digunakan oleh pihak pihak yang membutuhkan 
3. Hasil output SIMDA diperoleh secara cepat dan tepat waktu.

4. Hasil output SIMDA dapat dijadikan sebagai sumber informasi.

5. Hasil output SIMDA dapat diklasifikasikan menurut kepentingan masing masing bidang,
a) Bidang Perencanaan
b) Bidang Penatausahaan
c) Pelaporan Keuangan

c. Variabel Dependen

Variabel kinerja SIMDA ( $\mathrm{Y}$ ) berkaitan dengan kemampuan untuk memproses data melalui program program tertulis sebagai sarana pemerintah atau sektor publik dalam melaksanakan tugasnya untuk memberikan pelayanan kepada masyarakat. Kinerja SIMDA dijelaskan dengan indikator sebagai berikut:

1. SIMDA mampu membantu bidang/bagian berfungsi dengan baik

2. SIMDA sangat penting dalam kesuksesan kinerja bidang/bagian

3. SIMDA mampu meningkatkan kepuasan kerja operator

4. SIMDA dapat memberikan informasi yang dibutuhkan semua pihak, seperti : Bupati, BPK, dan masyarakat

5. SIMDA di dalam aplikasi digunakan untuk mengakses informasi guna memenuhi kebutuhan bidang/bagian keuangan

6. SIMDA dapat membantu mengerjakan tugas bidang/bagian keuangan

7. SIMDA dapat memberikan kontribusi dalam pencapaian tujuan dan misi instansi

8. SIMDA dapat melakukan penyesuaian pada berbagai kondisi baru sesuai dengan perkembangan kebutuhan informasi sekarang dan di masa mendatang

Analisis jalur merupakan perluasan dari analisis yang diperlukan pada jalur hubungan (network) variabel - variabel yang melibatkan lebih dari satu pertanyaan. Diagram jalur memberikan secara eksplisit hubungan kausal antar variabel model bergerak dari kiri ke kanan dengan implikasi prioritas hubungan kausal variabel yang dekat ke sebelah kiri. Keunggulan path dapat mengakomodir pengaruh langsung dan tidka langsung melalui variabel interviening. Hubungan langsung terjadi jika satu variabel mempengaruhi variabel yang lainnya tanpa ada variabel ketiga yang memediasi (intervening) hubungan kedua variabel. Hubungan tidak langsung adalah jika ada variabel ketiga yang memediasi hubungan kedua variabel, kemudian pada 
setiap variabel dependen akan ada anak panah yang menuju variabel ini dan berfungsi untuk menjelaskan jumlah variabel yang tidak dapat dijelaskan oleh variabel itu.

\section{Hasil dan Pembahasan}

\section{$\underline{\text { Hasil }}$}

Berdasarkan hasil koefisien jalur maka dapat dibuat persamaan berikut.

$Z=0,080+0,945 X_{1}-0,006 X_{2}+e$

$Y=0,082+0,938 X_{1}-0,008 X_{2}+0,02 Z+e$

1. Pengaruh variabel kemampuan teknik personal sistem informasi $\left(X_{1}\right)$ terhadap Kinerja SIMDA $(\mathrm{Y})$

Berdasarkan Hasil analisis data dapat dilihat untuk pengujian variabel kemampuan teknik personal sistem informasi terhadap kinerja SIMDA diperoleh nilai beta $(\beta)$ sebesar 0,938 dengan $\rho$-value sebesar 0,000 . Karena nilai $\rho$-value lebih kecil daripada $\alpha(0,000<0,05)$ maka $\mathrm{H}_{0}$ ditolak. Dengan demikian ada pengaruh signifikan kemampuan teknik personal sistem informasi terhadap kinerja SIMDA.

2. Pengaruh Variabel Program pelatihan pemakai $\left(X_{2}\right)$ terhadap kinerja SIMDA (Y)

Berdasarkan Hasil analisis data dapat dilihat untuk pengujian variabel Program pelatihan pemakai terhadap kinerja SIMDA diperoleh nilai beta $(\beta)$ sebesar 0,008 dengan $\rho$-value sebesar 0,858 . Karena nilai $\rho$-value lebih besar daripada $\alpha(0,000<0,05)$ maka $\mathrm{H}_{0}$ diterima. Dengan demikian ada pengaruh signifikan program pelatihan pemakai terhadap kinerja SIMDA.

3. Pengaruh variabel kemampuan teknik personal sistem informasi $\left(X_{1}\right)$ terhadap adopsi layanan(Z)

Berdasarkan Hasil analisis data dapat dilihat untuk pengujian variabel kemampuan teknik personal sistem informasi terhadap adopsi layanandiperoleh nilai beta ( $\beta$ ) sebesar 0,945 dengan $\rho$-value sebesar 0,000 . Karena nilai $\rho$-value lebih kecil daripada $\alpha(0,000<0,05)$ maka $\mathrm{H}_{0}$ ditolak. Dengan demikian ada pengaruh signifikan kemampuan teknik personal sistem informasi terhadap kepuasan kerja.

4. Pengaruh variabel program pelatihan pemakai $\left(X_{2}\right)$ terhadap adopsi layanan(Z) 
Berdasarkan Hasil analisis data dapat dilihat untuk pengujian variabel program pelatihan pemakai terhadap adopsi layanandiperoleh nilai beta $(\beta)$ sebesar 0,006 dengan $\rho$-value sebesar 0,890 . Karena nilai $\rho$-value lebih besar $\alpha(0,000$ $<0,05)$ maka $\mathrm{H}_{0}$ diterima Dengan demikian program pelatihan pemakai tidak berpengaruh signifikan terhadap kepuasan kerja.

5. Pengaruh variabel adopsi layanan(Z) terhadap kinerja SIMDA (Y)

Berdasarkan Hasil analisis data dapat dilihat untuk pengujian variabel adopsi layanan terhadap kinerja SIMDA diperoleh nilai beta $(\beta)$ sebesar 0,02 dengan $\rho$-value sebesar 0,045. Karena nilai $\rho$-value lebih kecil daripada a $(0,045<$ $0,05)$ maka $\mathrm{H}_{0}$ ditolak. Dengan demikian ada pengaruh signifikan adopsi layananterhadap kinerja SIMDA.

Perhitungan Analisis Jalur (Path Analysis)

Bagian ini menjelaskan perhitungan pengaruh variabel lingkungan kerja yang terdiri dari kemampuan teknik personal sistem informasi $\left(\mathrm{X}_{1}\right)$ dan program pelatihan pemakai $\left(\mathrm{X}_{2}\right)$ berpengaruh langsung dan tidak langsung terhadap kinerja $\operatorname{SIMDA}(\mathrm{Y})$, melalui variabel intervening adopsi layanan (Z). Apabila terdapat jalur yang tidak signifikan, maka diberlakukan trimming theory yaitu dengan menghilangkan atau menghapus jalur yang tidak signifikan. Kemudian dengan hasil struktur yang baru tersebut dihitung kembali masing-masing koefisien jalurnya (path coefficient)). Oleh karena itu jalur program pelatihan pemakai tidka dimasukkan dalam perhitungan jalur. Perhitungan jalur dari variabel yang terbukti signifikan. Berdasarkan Apabila terdapat jalur yang tidak signifikan, maka diberlakukan trimming theory yaitu dengan menghilangkan atau menghapus jalur yang tidak signifikan sehingga yang masuk dalam perhitungan jalur adalah pengaruh kemampuan teknik personal sistem informasi terhadap adopsi layanan dan kinerja SIMDA sedangkan program pelatihan dikeluarkan dalam perhitungan jalur karena tidak signfikan. Berdasarkan hasil perhitungan koefisien jalur pada lampiran, tampak bahwa total pengaruh variabel kemampuan teknik personal sistem informasi $\left(X_{1}\right)$ terhadap kinerja $\operatorname{SIMDA}(Y)$ adalah sebesar $95,6 \%$ dengan rincian pengaruh langsung sebesar 93,8\% dan pengaruh tidak langsung sebesar $1,8 \%$.

\section{Pembahasan}

Pengaruh Faktor Kemampuan Teknik Personal Sistem Informasi terhadap Kinerja SIMDA 
Berdasarkan data perhitungan analisis jalur dan pengujian hipotesis tampak bahwa faktor kemampuan teknik personal sistem informasi mempunyai pengaruh positif yang signifikan terhadap kinerja SIMDA. Keadaan tersebut terjadi karena adanya penilaian kerja yang merupakan kumpulan total dari kerja yang merupakan tugas dan ciri individu guna mencapai sasaran/target yang ditentukan pimpinan. Secara keseluruhan faktor kemampuan teknik personal sistem informasi berpengaruh terhadap kinerja SIMDA. Hal tersebut didukung dengan jawaban responden secara keseluruhan menunjukkan bahwa sebagian responden mempunyai persepsi sangat baik tentang kinerja SIMDA. Berarti operator SIMDA di OPD Pemerintah Kabupaten Bondowoso selalu berupaya dalam meningkatkan kinerja SIMDA.

Kemampuan teknik personal sistem informasi akan berpengaruh terhadap hasil yang dicapai oleh seorang operator SIMDA sehingga dapat mempengaruhi kinerja SIMDA pada sebuah instansi atau organisasi. Berdasarkan nilai perhitungan analisis jalur menunjukkan bahwa kemampuan teknik personal sistem informasi berpengaruh positif terhadap kinerja SIMDA Operator SIMDA di OPD Pemerintah Kabupaten Bondowoso. Berarti semakin tinggi kemampuan teknik personal sistem informasi operator SIMDA atas suatu pekerjaan maka akan semakin meningkatkan kinerja. Demikian juga sebaliknya, semakin rendah kemampuan teknik personal sistem informasi operator SIMDA kinerja yang diinginkan. Kemampuan teknik personal sistem informasi yang menunjukkan kemampuan operator SIMDA dalam melaksanakan pekerjaan, dalam menyelesaikan tugas yang diberikan akan mempengaruhi pola kerja dan hasil kerja operator SIMDA itu sendiri. Karena dengan adanya kemampuan teknik personal sistem informasi merupakan salah satu faktor yang mendukung untuk bekerja lebih giat sehingga hasilnya optimal. Dengan hasil yang optimal maka kinerja yang diharapkan akan lebih meningkat.

Kemampuan teknik personal sistem informasi operator SIMDA di OPD Pemerintah Kabupaten Bondowoso yang ada senantiasa dikembangkan dnegan berbagai penilaian operator SIMDA yang bermanfaat untuk optimalisasi tugas danjabatan yang diemban operator SIMDA. Oleh karena itu, operator SIMDA di OPD Pemerintah Kabupaten Bondowoso perlu ditingkatkan dengan kemampuan yang tinggi yang dilakukan dengan berbagai jenis pekerjaan sehingga dilakukan penilaian oleh instansi untuk meningkatkan kemampuan operator SIMDA di OPD Pemerintah Kabupaten Bondowoso. 
Hasil penelitian ini terlihat ada pengaruh tidak langsung dan langsung faktor kemampuan teknik personal sistem informasi terhadap kinerja SIMDA Operator SIMDA di OPD Pemerintah Kabupaten Bondowoso. Pengaruh tidak langsung melalui adopsi layanan. Hal itu menunjukkan persepsi terhadap kemampuan teknik personal sistem informasi yang tinggi akan menimbulkan adopsi layanan sehingga secara tidak langsung akan menyebabkan operator SIMDA melakukan pekerjaan secara optimal. Apabila hasil kerja optimal maka dapat meningkatkan kinerja SIMDA. Kemampuan teknik personal sistem informasi operator SIMDA di OPD Pemerintah Kabupaten Bondowoso yang dipersepsikan secara langsung berpengaruh positif terhadap adopsi layanan secara keseluruhan, demikian juga adopsi layanan yang dirasakan berpengaruh positif terhadap kinerja SIMDA.

Hasil penelitian ini sesuai dengan penelitian Jen et al. (2002) berpendapat bahwa semakin tinggi kemampuan teknik personal SIA akan meningkatkan kinerja SIA dikarenakan adanya hubungan positif antara kemampuan teknik personal SIA dengan kinerja SIA. Kemampuan Teknik Personal pemakai sistem informasi berperan penting dalam pengembangan sistem informasi untuk dapat menghasilkan informasi guna menciptakan laporan perencanaan yang akurat.

Pengaruh Faktor Program Pelatihan Pemakai Terhadap Kinerja SIMDA

Berdasarkan nilai perhitungan analisis jalur pengaruh langsung yang ditimbulkan program pelatihan pemakai tidak berpengaruh signifikan terhadap kinerja SIMDA. Program pelatihan pemakai tidka berpengaruh signifikan terhadap kinerja SIMDA pada Bagian Operator SIMDA di OPD Pemerintah Kabupaten Bondowoso. Berarti program pelatihan pemakai operator SIMDA atas suatu pekerjaan semakin tinggi tidak akan meningkatkan kinerja. Karena dengan adanya program pelatihan pemakai tersebut belum terlaksa dengan optimal sehingga kinerja sistem informais belum tercapai juga.

Program pelatihan pemakai operator SIMDA pada Bagian Operator SIMDA di OPD Pemerintah Kabupaten Bondowoso belum sepenuhnya diterapkan dengan karena penggunaan SIMDA masih tegrolong baru. Sehingga pelatihan yang diadakan juga masih kurang optimal. Seharusnya, pelatihan ditujukan pada kesadaran pentingnya informasi serta pendayagunaan teknologi informasi dan komunikasi (eliteracy), baik di kalangan pemerintah dan pemerintah daerah otonom maupun di kalangan masyarakat dalam rangka mengembangkan budaya informasi ke arah terwujudnya masyarakat informasi (information society). Peningkatan melalui 
pemberian penghargaan / apresiasi kepada seluruh sumber daya manusia bidang informasi dan komunikasi di pemerintah pusat dan daerah serta masyarakat yang secara aktif mengembangkan inovasi menjadi karya yang bermanfaat bagi pengembangan dan pelaksanaan e-government. Hasil penelitian ini tidak konsisten dengan penelitian Holmes dan Nicholls (dalam Komara dan Acep, 2005) dimana faktor program pelatihan pemakai berpengruh signifikan terhadap kinerja SIMDA Pengaruh Kemampuan Teknik Personal Sistem Informasi terhadap Adopsi Layanan SIMDA

Berdasarkan nilai perhitungan jalur terlihat ada pengaruh secara langsung yang diberikan faktor kemampuan teknik personal sistem informasi terhadap adopsi layanan Operator SIMDA di OPD Pemerintah Kabupaten Bondowoso. Berarti semakin tinggi persepsi terhadap kemampuan teknik personal sistem informasi operator SIMDA atas suatu pekerjaan maka akan semakin mudah operator SIMDA melakukan pelayanan terhadap masyarakat. Demikian juga sebaliknya, semakin rendah kemampuan teknik personal sistem informasi operator SIMDA maka adopsi layanan juga semakin rendah. Kemampuan operator SIMDA akan menunjang bagaimana operator SIMDA tersebut dapat menikmati hasil kerja yang dilakukan dengan segala ciri khas yang dipunyai. Setiap operator SIMDA memiliki kemampuan baik fisik dan kognitif serta sikap dan minat yang berbeda-beda dalam melakukan pekerjaannya sehingga hasil yang diterimanya akan menimbulkan penerpaan layanan sistem informasi berbeda. Berdasarkan hasil karakteristik responden menunjukkan bahwa jumlah responden laki-laki hampir dua kali lipat dibandingkan dengan jumlah responden perempuan. Besarnya jumlah laki-laki operator SIMDA lebih banyak laki-laki disebabkan lebih banyak memenuhi persyaratan yang ditentukan terutama untuk bagian sistem informasi.

Kemampuan teknik personal sistem informasi operator SIMDA di OPD Pemerintah Kabupaten Bondowoso yang sudah dipantau dengan segala jenis sistem dan peratutan sehingga pihak pemerintah menginginkan operator SIMDA memiliki kemampuan operator SIMDA yang diperlukan oleh instansi. Oleh karena itu pengembangan kemampuan teknik personal sistem informasi yang berupa kemampuan bisa dilakukan dengan peningkatan pendidikan yang lebih tinggi jenjangnya, adanya pelatihan skill dan lain-lain.

Pemakai atau pengguna merupakan suatu hal yang tidak terlepas penerapan teknologi, selain itu keberadaan manusia sangat berperan penting dalam penerapan 
teknologi. Kecanggihan teknologi yang ada tidak akan ada artinya jika dalam perencanaan sistemnya tidak memperhatikan faktor manusia sebagai pemakainya, maka dapat dipastikan akan terjadi banyak hambatan yang disebabkan adanya ketidaksesuaian antara teknologi yang digunakan dengan pemakainya.

Adopsi layanan sistem informasi dipengaruhi oleh kemampuan teknik personal. Personal yang memiliki kemampuan dalam penggunaan SIA akan dapat mengoperasikan sistem dengan baik sehingga kinerja SIA lebih tinggi, hal ini menunjukan semakin efektifnya penggunaan SIA (Hary dan Gustiyan, 2014). Apabila kemampuan teknik personal semakin baik maka adopsi layanan informasi yang diberikan juga akan semakin baik. Hasil ini tidak konsisten sebagaimana pada penelitian Fani dan Nanda (2012) menemukan bahwa kemampuan teknik personal berpengaruh positif terhadap adopsi layanan informasi. Hasil ini tidak sesuai juga dengan penelitian Wilayanti et al. (2015) menemukan bahwa kemampuan teknik personal dapat meningkatkan adopsi layanan sistem informasi.

Pengaruh Program Pelatihan Pemakai Terhadap Adopsi Layanan SIMDA

Program pelatihan pemakai diperlukan dalam meningkatkan kemampuan operator SIMDA. Berdasarkan nilai perhitungan analisis jalur tidak terdapat pengaruh yang ditimbulkan variabel program pelatihan pemakai terhadap adopsi layanan operator SIMDA secara langsung. Berarti semakin baik program pelatihan pemakai belum tentu meningkatkan adopsi layanan. Hal itu dikarenakan pelatihan yang dilakukan masih jarang sekali dankurang terarah. Adanya tingkat program pelatihan pemakai individu juga didukung dengan karakteristik responden dari tingkat pendidikan responden terbanyak adalah SMA sehingga pemahaman akan program pelatihan sering kali masih diabaikan. .

Program pelatihan pemakai operator SIMDA pada dasarnya perlu diterapkan pada operator SIMDA karena dengan program pelatihan pemakai maka operator SIMDA memiliki kemampuan melayani masyarakat dnegan bisa mengoperasikan SIMDA dalam pekerjaan sehari-hari. Sistem yang mempunyai peran penting dalam organisasi / instansi / perusahaan dan merubah cara menangkap, memproses, menyimpan dan mendistribusikan informasi dengan tujuan untuk memberikan kemudahan bagi para akuntan untuk menghasilkan informasi yang dapat dipercaya, tepat waktu, lengkap, dapat dipahami dan teruji. Hasil penelitian ini tidak konsisten dengan Wiliandari (2016) menyatakan bahwa pelatihan sistem informasi yang di berikan mampu meningkatkan adopsi layanan informasi. 
Pengaruh Faktor Adopsi layanan terhadap Kinerja SIMDA

Adopsi layanan merupakan perasaan gembira atau positif yang dimiliki oleh operator SIMDA terhadap pekerjaan itu sendiri, ganjaran yang diterima ataupun perasaan yang berhubungan dengan dirinya. Karena itu maka adopsi layanan menyangkut perasaan yang bukan berarti tidak perlu diperhatikan sebab adopsi layanan akan tercermin pada hasil pekerjaan. Oleh karena itu, pimpinan sebagai manajer dituntut lebih profesional agar mampu menimbulkan adopsi layanan pada operator SIMDA.

Berdasarkan pengujian dengan analisis jalur tampak bahwa adopsi layanan berpengaruh positif terhadap kinerja SIMDA terbukti signifikan. Semakin tinggi adopsi layanan yang dicapai oleh operator SIMDA maka akan meningkatkan kinerja SIMDA. Hal itu disebabkan adanya layanan yang dicapai operator SIMDA akan menyebabkan adanya dorongan intrisik untuk mencapai hasil kerja yang diharapkan akan optimal. Adanya hasil penelitian ini juga didukung dengan jawaban responden secara keseluruhan yang menunjukkan bahwa sebagian responden mempunyai persepsi sangat setuju tentang kinerja. Hal itu menunjukkan bahwa operator SIMDA di OPD Pemerintah Kabupaten Bondowoso mempunyai usaha dalam meningkatkan kinerja.

Pengaruh langsung yang ditimbulkan oleh kepuasan terhadap kinerja SIMDA tersebut adanya adopsi layanan yang dicapai operator SIMDA akan berpengaruh secara langsung terhadap kinerja SIMDA Operator SIMDA di OPD Pemerintah Kabupaten Bondowoso.

\section{Kesimpulan}

Berdasarkan hasil penelitian dan pembahasan dapat disimpulkan bahwa kemampuan teknik personal sistem informasi berpengaruh signifikan terhadap kinerja SIMDA. Semakin baik kemampuan teknik personal maka kinerja SIMDA semakin baik. Pelatihan pemakai sistem tidak berpengaruh terhadap kinerja SIMDA. Pelatihan yang kurang optimal tidak meningkatkan kinerja SIMDA. Kemampuan teknik personal sistem informasi terhadap adopsi layanan SIMDA. emampuan operator yang semakin meningkat akan meningkatkan adopsi layanan SIMDA. Pelatihan pemakai sistem tidak berpengaruh terhadap kinerja SIMDA. Pelatihan yang kurang optimal tidak meningkatkan adopsi layanan SIMDA. Adopsi layanan SIMDA berpengaruh signifikan terhadap kinerja SIMDA. Semakin baik adopsi layanan maka kinerja SIMDA semakin baik. 


\section{Saran}

Saran yang dapat diajukan dalam penelitian ini antara lain: (1) Perlunya memperluas objek penelitian dan jumlah sampel, tidak hanya satu bagian saja sehingga lebih dapat dijadikan acuan bagi kepentingan generalisasi permasalahan. Juga perlu menambah populasi penelitian agar data yang lebih kompleks dapat terbaca dengan mudah; (2) Perlu ditambahkan metode wawancara pada saat pengumpulan data untuk menghindari kemungkinan bias atau tidak obyektif dari responden dalam mengisi kuesioner; (3) Bagi pmerintah Kabupaten Bondowoso dapat meningkatkan kinerja sistem informasi dengan terus melakukan evaluasi dan pengembangan terhadap sistem yang sesuai dengan lingkungan intern instansi dan prosedur yang telah ditetapkan, sehingga dapat terus bersaing dalam lingkungan bisnis yang semakin kompetitif.

\section{Daftar Referensi}

Alfian, Mohammad, 2014. Analisis Faktor Pendukung Implementasi SIMDA dan Pengaruhnya Terhadap Kualitas Laporan Keuangan Pada SKPD, 3rd Economics and Business Research Festival, Edisi 1.

Almilia, L.S. Briliantien, dan Irmaya, 2006. Faktor-faktor yang mempengaruhi kinerja SIMDA Akuntansi (SIA) pada Bank umum Pemerintah di Surabaya. Jurnal Bisnis dan Akuntansi. Surabaya.

Almilia, Luciana Spica dan Briliantien, Irmaya. 2007. Faktor-Faktor yang mempengaruhi Kinerja SIMDA Akuntansi. Jumal Akuntansi.

Badan Pemeriksa Keuangan Republik Indonesia. 2015. Ikhtisar Hasil Pemeriksaan Semester II Tahun 2015

Badan Pemeriksa Keuangan Republik Indonesia. 2016. Ikhtisar Hasil Pemeriksaan Semester I Tahun 2016.

Briliantien. 2007. Faktor-faktor yang Mempengaruhi Kinerja SIMDA Akuntansi pada Bank Umum Pemerintah di Wilayah Surabaya dan Sidoarjo. Surabaya : STIE Perbanas Surabaya

Fani, Yogita Nanda. 2012. Pengaruh Kecanggihan Teknologi Informasi, Kemampuan Teknik Pemakai, Dan Dukungan Manajemen Puncak Terhadap Kinerja SIMDA Akuntansi Studi Empiris Pada PT. PLN (Persero) Area Bali Utara (Kantor Pusat). e-Journal S1 Ak Universitas Pendidikan Ganesha Jurusan Akuntansi Program S1. Volume 3, No. 1

Hary, Gustiyan. 2014. Analisis Faktor - Faktor Yang Mepengaruhi Kinerja SIMDA Akuntansi Pada Bank Perkreditan Rakyat (BPR) Di Tanjungpinang. Vol. 12, No. 1, Mei 26-40

Hashim , Muhammad, Asfandyar Yousaf Dan Muhammad Jehangir .2012. The impact of Management Information System on the Overall Performance and Efficiency of the Workforce of the Accountant General (Peshawar): A Research Base Study . 
International Journal of Academic Research in Accounting, Finance and Management Sciences Volume 2, Issue 2 (2012)

Jen, Fung, Tjhai. 2002. Faktor - Faktor Yang Mempengaruhi Kinerja SIMDA Akuntansi. Jurnal Bisnis Dan Akuntansi Volume IV No. 2.

Karikari, Ama F. , Peter Agyekum Boateng dan Evans O. N. D. Ocansey.2015. The Role of Human Resource InformationSystem in the Process of Manpower Activities. American Journal of Industrial and Business Management, 5, 424-431.

Komara, Acep. 2005. Analisis Faktor-Faktor yang mempengaruhi Kinerja SIMDA Akuntansi. Simposium Nasional Akuntansi 8. Solo

Laporan Hasil Pemeriksaan BPK-RI atas Laporan Keuangan Pemerintah Daerah Kabupaten Bondowoso TA. 2015, No. 53.B/LHP/XVIIIJATIM/05/2016, tanggal 30 Mei 2016

Lestari, Indar Eva, 2010. Pengaruh Rekrutmen dan Pelatihan Terhadap Kinerja Karyawan Pada PT. Traktor Nusantara Pekanbaru, Jurnal Ekonomi Volume 1 No.4 Universitas Brawijaya

Situs Resmi BPKP 2017, Pengenalan Sistem Informasi Manajemen Daerah (SIMDA)

http://www.bpkp.go.id/sakd/konten/333/Versi-2.1.bpkp

Srimindarti, Cecilia \& Puspitasari, Elen. 2012. Kinerja SIMDA Akuntansi (SIA) Di tinjau dari kepuasan pemakai dan pemakaian SIA yang dipengaruhi oleh partisipasi, kemampuan, dan pelatihan pemakai SIA. Jurnal Akuntansi. Semarang.

Wilayanti, Ni Wayan dan Dharmadiaksa, Ida Bagus. 2015. Keterlibatan Dan Kemampuan Teknik Personal Pada Efektivitas Penggunaan Sistem Informasi Akuntansi. E-Jurnal Akuntansi Universitas Udayana Vol.15.2. Mei 1310-1337

Wiliandari.2016. Pengaruh pelatihan sistem informasi terhadap pelayanan sistem informasi Rumah Sakit. E-Jurnal Akuntansi Universitas Udayana Vol.11.Juni. $1310-1337$

Yulian, A. 2011. Efektivitas Sistem Informasi Manajemen. Jurnal IImiah Volume 4 Nomor 2 Universitas Sriwijaya 